\title{
Albanian Women of Macedonia in Political Life
}

\section{lbish Kadriu}

State University of Tetova

ibish.kadriu@hotmail.com

\section{Doi:10.5901/jesr.2014.v4n2p199}

\begin{abstract}
The democratization of a country is measured by the level of representation of different groups of society, especially women. Women comprise half of the electorate, and everyone agrees that Albanian women in Macedonia are politically underrepresented. Despite the political and legal efforts, yet they are not present in political life. The impact factors are: the lack of education, their huge daily engagement in households, poverty and lack of employment. These factors are reinforced by the patriarchal mentality, as a result of which women are not engaged in politics and they have no ability to engage in politics, and as a result the decisions are made on her behalf in various forms, including the phenomenon of family voting. Albanian women in Macedonia are positioned in the margins of politics, a position which is completely invisible and without decision- making influence. Their exclusion is an indication of mentality and the traditional way of life of the Albanians in this country and complete inequality of women in family and society. Through forms of power and gender domination, women's activity in political life is limited. The purpose of this research is to draw the attention of society, especially of the Albanian men in Macedonia, that the inclusion of women in political decision-making is one of the elements that must be changed in the way politics is done, because its absence hinders the achievement of consolidated democracy according to the concept of liberal democracy. In this article we will discuss the reasons that affect the women's involvement in politics. The cultural and historical factors have their role in creating the conditions for the participation of women in public life in the past and during the postcommunist transition period when they were completely neglected. The research is based on the use of mixed methodological approach (structured interviews, free conversations and statistical analysis). This paper attempts to provide answers to the question about the place, role, and incorporation of Albanian women in politics, and in the context of democratic processes of Albanian family and society in Macedonia. This research has proven that Albanian women in Macedonia are politically more marginalized than for e.g. the women of Macedonian community.
\end{abstract}

Keywords: politics, Albanian women, participation, emancipation

\section{Introduction}

The fate of women is not a product of fatalism, but of a patriarchal civilization, which defined women's place and position in this world. The reason why women have not achieved to assume the world more profoundly derives from her position, not from her nature. She is born free, with equal potential to prove herself as an individual human being. Someone else usurps her rights, and it imposes slavery to her. Even when her rights are recognized in the abstract, the long-lasting habit (traditions, customs) make impossible for her to find concrete expression in life (Simone de Bouvoir).

In the Republic of Macedonia, despite the efforts of many different actors of society in finding a solution for Albanian women empowerment, however, the link that connects women voters with women in politics is still missing. Whenever elections approach, the problem of underrepresentation of Albanian women in politics appears and is reactivated. Representation through the fulfillment of gender quota remains only a formal attempt, enough to meet the legal requirements, or a trend, and not a long-term solution and a continuous or natural increase, as a need of time.

In recent years, political parties representing the Albanians in Macedonia are introducing more women on party lists and their leadership forums. Do we have to deal with a real emancipation of the Albanian politics among us, or just with nominal function, only to attract as many votes from this group of voters as possible?!

Macedonia's Albanians society is a traditional society, because the woman is the pillar of the house, the husband is still the breadwinner, the decision-maker, while women in politics are still only a political decor. Although the situation is changing, even when women work or participate in household requirements or when hold minimally important social positions, never take part in decision making. This situation unveils the place and role they actually have in society and politics. Education of the Albanian woman appears to have opened avenues for women to give their contribution to the family, the society and the highest state bodies. With the democratization of higher education, especially the opening of 
the State University of Tetova and South East European University, many Albanian women have obtained titles and degrees, so their role in society, in the enhancement of democracy, political participation and decision-making, was expected to be more noticeable.

Despite employment or education level, patriarchal society has defined many tasks for women regarding the gender role, related to home and family. Employment in most cases, has not freed women from many obligations, but most often represents an additional obligation. In general, unemployed women, who constitute the majority of Albanian women in Macedonia, have unlimited work hours at home. They lack the time to watch television programs, which will affect the shaping of political persuasion, and consequently would have voted independently. Political parties begin to be preoccupied with the issue of women's representation, shortly before compiling the lists. The big difference of wages in two power levels, dictates the quality of representation of women. Political parties are concerned with the fact that women who are to enter the election list should be obedient to the party. With few exceptions, women who enter politics do not represent women, but men, because proposals for inclusion come from men themselves. In municipal assemblies, the situation is even worse. Besides the lack of preparation to represent concepts of political programs, they are not even able to initiate issues or provide solutions to the problems of women in the community they live at. In all municipal assemblies lacks the representation of certain categories of women such as: housewives, unemployed women, or craftswomen, employed women.

\section{Women's Empowerment Lies in Their Education and Emancipation}

Firstly, it must be understood that the women's issue is not an issue of competition or coming to power, but a matter of equality, and second, it is a matter of education and emancipation. The women's issue, along with a number of other issues, is raised whenever there is an event that has to do with women, March 8, elections, etc. Some say that women face the problem of presence in the highest decision-making levels, and therefore a qualitative intervention should be made. Others say that women need more freedom to do what they want without feeling forced. Some say that women need more education, emancipation; then the need for power, independence, esteem, etc. All these suggestions seem all right, and at the same time partial, each of them important for discussion and deep analysis, depending on the place, time and context. Many studies in this area come to conclusions that the problem of women is a complex problem, given its nature, tradition, social exclusion, gender discrimination, not from neglecting, etc. (Sokol, M \& Danaj, L. S. \& Picari, B., 2006).

Cultural, traditional and modern structures, whether they were social relationships or family relationships, etc., reflect a dominant mentality, relationship in which women are always in the background. This dominance reaches career women, women in leadership positions in other important positions, as well as in politics.

So what should we do to overcome this problem? Obviously it's not enough for parties with men giving striptease for women in Tirana, where men make lunch in Prishtina, or when Tetovo men buy (once a year) their wives flowers. It is assumed that bigger involvement decision-making of women in politics can bring changes to social policy and children's health, building of schools, roads, parks, recreational facilities, etc., and women contributing to the improvement of living conditions and quality of life in society. The challenges are evident, beginning from the payment of job salary, the impact on central institutions and economic life, the same care to education and health of women, sexual violence, the way of coexistence and the problem of women in society, etc.

Despite the progress, the image and portrayal of Albanian women in Macedonia remains a highly topical issue. Perhaps the dominance of men in politics explains the stereotype, as well as tradition, emancipation, as well as education. Gender equality is not only a good thing to do. If women are educated, not violated, their families will flourish. If women have a chance to work and earn as equal partners in society, their families will flourish, along with them the society will move forward and become more civilized. Statistics show that women's participation in business and in politics grows, enriches, and provides a stronger and more prosperous business and society. The role of women should be the same as in the family. A survey conducted in 2013 in Macedonia has suggested that $34 \%$ of citizens stated that the world would be a better place for living if women take leadership in politics. Everyone has a part in the rights of women. Although with difficulty, and slowly, it can be said that in Macedonia finally is widespread the belief that women should be treated the same as men are, in social and political life, which should have a meritorious place. The reality is totally different. Consequently, women do not feel as autonomous actors that participation in politics is important and following the same reason, we do not think that involvement in politics will bring any benefit to them. The survey data on Albanian women's participation in politics in Macedonia shows that about $15-20 \%$ of them do not vote at all. The reasons are often different from disinterest in politics, to the lack of time and others voting instead of them. So, the non- 
participation of women in politics is due to the lack of tradition and mentality, where women could not express the personal opinion, where politics is not a job for women, adding the fear of expressing a different opinion in order to keep interpersonal relationships intact. Consequently, the homogeneity of political opinion within the family. Family voting is a situation in which women have no impact and cannot vote apart from their family. The results of this research show that only $2 \%$ of the sample, female employees have income of over thirty thousand denars (500 $€$ ), while $70 \%$ of the sample live in traditional families (spouses, their children, sometimes parents, brother or sister), and the same percentage (70\%) are unemployed women. This research has shown that the increased participation of Albanian women in politics, here in Macedonia, can be achieved by the employment growth (63\%), education (78\%), giving up of traditional way of living (78\%), increased activity and organization of women (72\%), etc. On the other hand, over $90 \%$ of the sample are of the opinion that women must engage in politics; that the Albanian women are very little engaged in politics were declared (75\%), and if we want to advance the Macedonia's Albanian society, we need educated women (95\%); these answers are compatible with the answers to the question if women's place is at home (4\%), while $94 \%$ of the sample completely agree that the female is the pillar of family and society, in response to the collision with the previous rates. Regarding the causes of exclusion of women from politics, $40 \%$ think to blame the Albanian tradition, $38 \%$ women passivity, lack of education $20 \%$ and $60 \%$ of the sample stated that women can contribute more than men in politics.

\section{Research Results}

This research has proven that the participation of Albanian women in politics as a form of representation in Macedonia does not correspond to democratic standards. In the group of citizens who are not actively involved in politics are women also, whose representation in politics despite quotas and percentages at all levels is very low. However, even within this group it is noted that women in rural areas are also excluded from politics, while uneducated women are fully discriminated. Uneducated women, both in towns and in villages, serve only as voting machinery, have reduced their political participation to the extent that they become apathetic and not considered important to be included in political parties at different decision-making levels, in short becoming invisible. By raising the issue of women aiming the equality and emancipation, the solution of the problem cannot be partial. So, there can be no improvement of women's situation only, without improving the society as a whole. First, the gender equality and empowerment of women is a long way to go (A. Reader, Mona. Lena \& Sarah Child's Kroole, 2010). On the other hand, the participation of women cannot be a matter of a political option, either red or blue. Models factoring women from developed countries speak for examples that show that women have to work together, however organized with the support of society and institutions, in order to succeed. Laws and political volunteerism are important, but not enough. Albanian women in Macedonia, over twenty years after democratization, should become part of the debate and the real political decision-making, not only to fulfill the percentages. The period of democratization, the same as the transition period after the socialist period, was not accompanied by a qualitative change to change the concept of democratic processes in the sphere of gender equality, because the democratization of society is measured by the level of representation of different groups of society, so, that of the women, too. Despite the growing number of women who are educated and employed, they still remain far from the requirements of the time. The factors that have contributed to this are: old fashioned way of living, unemployment, tradition, passivity, respectively acceptance of the shadowy role of women and huge loads of daily work. These factors are reinforced by the patriarchal mentality, according to which the woman must not and has no ability to deal with politics, and therefore the decisions are taken in her behalf in various forms, including the phenomenon of family voting. Consequently, Albanian women in Macedonia are positioned away from important events in political decision-making, a position where she is completely invisible. Their exclusion is an indication of failure of the democratic order in Albanian society in Macedonia and the fact that the process of democratization is ongoing. As long as women do not engage in the public life, especially in political life, we can't talk about a consolidated democratic order. Despite the employment or education level, patriarchal society has defined many tasks for women within the role of gender, which are related to home and family (Ibrahimi, Xhylije, 2013). Employment in most cases, has not freed women from many obligations, but it's an additional obligation. Let's not talk about employed women, which however, are included in the public life and have more opportunities for access to information. Generally, unemployed women, who constitute the majority of women in society, have unlimited work time at home. They lack the time to watch television programs, which will affect the shaping of political persuasion, which consequently would vote independently. Women need two aspects, to obtain and maintain our right position in society: economic and emotional independence, says Ulrike Lunacek, and this requirement applies to Albanian women in Macedonia.

Another part of the problem, the greater one, due to the responsibility, is constituted by women in politics. Political 
parties begin to be preoccupied with the issue of women's representation, shortly before compiling the lists. The big difference of wages in two power levels, dictates the quality of the representation of women. Most political parties are concerned that the woman, who enters the list of general elections, should be more audible. At the local level the situation is even worse. Besides the lack of training to represent concepts of political programs, they are not even able to raise serious issues or provide solutions to the problems of women in the community where they live. Therefore, it is important to work with women, not just a month before the nomination, but since the first day after elections (Darcy, R., Welch Sulsan, \& Janet Clark., 1994). Since in the patriarchal environment engagement in politics is another additional task for women, which is already overburdened with family and home obligations, one should consider facilitating methods for this commitment. One of these solutions would be allocation of a budget by the political party for providing child care services, when these women are engaged in an activity. The overall conclusion on the problem of factoring Albanian women in Macedonia is that the presence of women in politics is still low and that some of them have more aesthetic rather than a political function.

The examples we encounter in everyday life are numerous and quite denouncing by the media. You can bribe more easily a male teacher than a female one, a male customs officer than a female customs officer, a male politician than a female politician, etc. We believe that uncorrupted courts and a free press are the most important factors to create an uncorrupted society where citizens have faith in those who govern them and this role more than by any other could be played by women who are less corrupted.

Albanian society is a relatively nihilistic society, because higher and medium levels of power held by men. Although women sometimes cover minimally important positions, they have never had freedom in the decision-making, from which emerges the leading indicator of importance they would have in politics and governing structure. The education of Albanian women in Macedonia, the same as men's, has opened the paths for women to give their contribution in the highest state bodies, because they possess an equal culture as men do. Many women have obtained scientific degrees and speak foreign languages very good and their role in the development of democracy would be more primary rather than when a state is governed only by male staff.

\section{References}

Beqja, H. (2002). Gruaja, kjo qenie e shenjtë.Tiranë.

Derguti, A. (2014). Gratë dhe politika: gazeta Tribuna/ 07.08.2013 Prishtina press.

Butler, E. Pamela. (2008). Vetëpohimi i gruas. Tiranë: ILAR.

Dervishi, Z. (2001). Gratë në syrin e ciklonit të sfidave dhe perspektiva,Tiranë:Jerusalem. Elias, N. (1978).The civilizing process, The history of manner.Basil Blakwel: Oxsford. Mazreku, S. (2012). Mbi politikën dhe demokracinë. Tiranë Intergrafika. Fullani, A. (1999). Të drejtat ligjore të grave.Tiranë. Sokoli, M.\& Danaj, L. S. \& Picari, B.(2006). Përfaqësimi dhe cilësia e demokracisë në Shqipëri: Një perspektivë gjinore. Tiranë: Pegi.

Ibrahimi, Xh. (2013). Gratë dhe politika: Kriteri i meritës duhet të vlejë për të dy gjinitë, 14. shkurt: Zemra Shqiptare. Shkodra, M. (2014).Gratë në politikë vetëm "përfaqësim", apo të rëndësishme? E premte, 14 Shkurt 2014/ portal Indeksonline. Ulrike, L. (2012). Gra të njëmendta: Koha ditore, enjte 8 mars. Tahiri, L. (2012). Feminizmi sot: nevojë apo ekstravagancë: Koha ditore, enjte 8 mars. Pupa, A. Fuqizimi i gruas ne vendimmarrjen lokale, Rrjeti i grave ne politike, eksperienca dhe bashkepunimi: Rrjeti barazi në vendimarrje.

Sadikaj, D. (1982). Lëvizja për emancipimin e plotë të gruas në vitet 1967-1970: Tiranë: Akademia e Shkencave të Shqipërisë. SelaKastrati, F. \&Rusi, M. (2009). Dhuna ndaj gruas në Maqedoni dhe Kosovë. Tetovë. Angela, H. P. (1998). Female Empowerment: The Influence of Women Representing Women. Lincoln: University of Nebraska.

Andersen, K. (1975). Working Women and Political Participation. American Jounal of Political Science 19:439-454.

Bennet, S. E. \& Linda, M. B. (1992). From Traditional to Modern Conceptions of Gender Equality in Politics: Gradual Change and Lingering Doubts. Western Political Equality 45:93-11.

Conover, P. J. (1988). Feminists and the Gender Gap.: Journal of Politics 50:985-1010.

Darcy, R., Sulsan Welch, \& Janet Clark. (1994).Women, Elections, and Represen-tation. Lincoln, NE: University of Nebraska Press. A. Reader, Mona. Lena Kroole \$ Sarah Child's. (2010).Women, Gender, and Politics.Oxford. University press.

Udhëzues mbi çështjet e barazisë gjinore në standardet ligjore dhe jurisprudencën kombëtare e ndërkombëtare: shtypshkronja. Tiranë: Pegi. 